\title{
FLEXIBILITY OF THE APPLICATION OF VARIOUS ISLAMIC SCHOOLS OF THOUGHT IN SOME ISSUES RELATING TO HIBAH; STUDY ON PROVISIONS IN MALAYSIAN LAW AND OTHER COUNTRIES
}

\author{
By: \\ Zulkifly bin Muda
}

\begin{abstract}
Hibah is a form of gift in the same category as hadiyyah and sadaqah. The article attempts to elaborate the concept of hibah in terms of its validity in the case of apostasy of the giver, its conditions and implementation pertaining to al-Mu'atah, al-Qadb and Marad al-Maut in several Islamic countries. The article also covers the withdrawal of hibah and its legal procedures and implications. In the elaboration, cases are cited to indicate the implication and related problems.
\end{abstract}

\section{DEFINITION OF HIBAH (GIFT)}

Hibah means gift. It is derived from the word وهب يهب وهبا وهبة Technically, it means to give the right of ownership of something (to a person) without any return or consideration. ${ }^{2}$

1 Al-Munjid fi al-Lughat wa al-I'lam, Beirut: Dar al-Masyriq, p. 920; Mahmud Yunus (n.d.), Kamus Arab-Indonesia, Jakarta: Yayasan Penyelenggaraan Penterjemahan Pentafsiran al-Quran, p. 507.

2 Al-Syarbinì, Muḥammad b. al-Khatib (1958), Mughni, Qāherah: Matba'ah Mușțafā al-Ḥalabì, vol. 6, p. 273. 
Jurnal Fiqh: No. 3 (2006)

The word "without any return or consideration" means majjanan or free of any charge. ${ }^{3}$ Hanafi jurists did not include the condition "without any return or consideration." It means that it may happen without or with return or consideration. Hibah (gift) is different from sadaqah (alms), 'ariyah (lending), wasiyyah (will) and hadiyyah (bounty). Sadaqah is to give a sum of money or property to a person in need of such money or property in order to obtain rewards from Allah. "Ariyah is to lend certain property to a person in order for him to obtain benefit from such property for certain period of time. ${ }^{6}$ Wasiyyah is to give the right of ownership of certain property upon the death of the owner or the testator. Hadiyyah means a gift to a person to show the giver's respect or love to him. ${ }^{7}$ The writer views that hadiyyah possesses the same concept and definition as hibah. It is due to a reason that hibah generally is based on the concept of love and infatuation which is similar to hadiyyah. The other evidence to show that both hibah and hadiyyah share the same feature is that scholars had relied on the permissibility of hibah based on the authorities which support the permissibility of hadiyyah which will be discuss after this.

\section{AUTHORITIES ON PERMISSIBILITY OF HIBAH}

Islamic scholars unanimously agreed that hibah is permissible. They based their opinion on several authorities, inter alia:

3 Yasin Daradakah (1974), Nazariyyat al-Gharar fi al-Shari'at al-Islamiyyah, Amman: Wazarah al-Awqaf, vol. 2, p. 208.

4 'Uthman ibn Ali (n.d.), Al-Bahr al-Ra'iq, Kaherah: Dar al-Kitab alIslami, vol. 7, p. 309.

5 Wahbah al-Zuhaili (n.d.), al-Figh al-Islāmì wa Adillatuhu, 8 j. c. 3. Beirut: Dār al-Fikr, vol. 5, p. 5.

6 Al-Sarakhsí, Syam al-Dīn (1986M/1406H), Beirut: Dār al-Ma'rifah, vol. 11, p. 133; Syarbini, op.cit., vol. 2, p. 264.

7 Ibid. 
i. The saying of Allah which means to the effect that "When you are greeted with a greeting, greet in return what is better than it, or (at least) return it equally..."

Some scholars interpreted the word "tahiyyat" or greeting in this verse is equivalent to the word gift. Some of them interpreted it as the giving of salam. The first view is accurate because Allah had encouraged Muslims to reply a greeting in the better way or in equal way. The reply may occur by way of giving a gift, not salam. ${ }^{9}$

ii. Saying of the Prophet s.a.w which means "Give gifts among you so that it will increase love among you."10

\section{SCHOLAR'S OPINION ON THE EFFECT OF CONVERSION OF RELIGION TOWARDS HIBAH}

If a person apostatized from the religion of Islam, and then he creates hibah, the jurists were in different views with regards to the validity of such hibah:

First View: Such hibah is valid. This is the view of Abu Yusuf and Muhammad ibn al-Hasan. ${ }^{11}$ Their authorities are:

i. The right of ownership of an apostate person is not affected by his apostasy, but by his death (either by usual way or by death punishment). The right of ownership of property of an apostate person before his death is still endured by possibility of his has repentance and return to Islam. ${ }^{12}$

\footnotetext{
Al-Qur'an (4: 86).

Daradakah, vol. 2, p. 209.

1 Al-Syawkāni, Muhammad ibn 'Alī (n.d.), Nayl al-Awtār Syarh Muntaq al-Akhbār, Qāherah: Dār al-Turāth, vol. 5, p. 367. Narrated by Abu Hurairah. According to al-Hafiz, the chain of narration of this hadith is sahih.

11 Al-'Ayni, Abū Muhammad Maḥmūd b. Aḥmad (1990M/1411H), alBinyat fi Syarh al-Hidāyah, j. c. 2: Beirut: Dar al-Fikr, vol. 6, p. 714.

12 Al-Syarakhsi, op.cit., p. 103.
} 
Jurnal Fiqh: No. 3 (2006)

ii. Apostasy gives effect to the blood honor of the apostate person only, not to his properties. That is the reason why he should be killed if he refused to repent. His properties were still under his possession until the punishment imposed upon him. His status is similar with a person who commits adultery and to be punished by stoning, his right over his properties still exists although his blood honor does not exist anymore. ${ }^{13}$

Second view: Hibah made by an apostate person at the time of his apostasy is not valid. This view is uttered by Imam al-Shafi' $\bar{i}$ in his qaul jadid, ${ }^{14}$ Abu Bakr (a Hambali's scholar) ${ }^{15}$ and Suhnun (a Maliki's scholars). ${ }^{16}$

Their authorities are:

i. The right of possession of property of an apostate person is loss soon after he committed such offence. Therefore, his dealing with his property is not valid. ${ }^{17}$

ii. Imam al-Shafi' $\bar{i}$ in his qaul jadid did not accept the existence of mauquf contract (which has been freezed for a while).${ }^{18}$ Contract is only divided into two, valid and invalid.

Third view: Hibah made by an apostate person at the time of his apostasy is frozen (mauquf).${ }^{19}$ What is meant by mauquf here is that, his contract is based on his attitude. If he

\footnotetext{
Ibid., p. 105.

Al-Nawawì, Abū Zakariyyā,

Jabir al-Fudailat (1987), Ahkam al-Riddah, Amman: Dār al-Arabiyyah, p. 376.

16 Syams al-Dīn Muḥammad Abū 'Abd Allah Muḥammad al-Kharāsyī (n.d.), al-Khursyi’ al-Muhktasr Sayyidī Khalīl, Beirut: Dār al-Fikr, vol. 8, p. 69.

17 Ibn Qudāmah, al-Dīn Abū Muḥammad 'Abd Allah b. Aḥmad b. Muhammad (1983M/1403), al-Mughnì, Beirut: Dār al-Kitāb al-'Arabi, vol. 9 , p. 10.

18 Al-Syarbini, op.cit., vol. 4, p. 143.

19 Aini, op.cit., vol. 6, p. 714; Fudailat, op.cit., p. 376.
} 
reverts to Islam his hibah is valid without having to make a new 'aqd. On the other hand, if he remains to be an apostate person, his 'aqd of hibah is not valid. This is the view of Imam Abu Hanifah, ${ }^{20}$ Imam al-Shafi' $\bar{i}$ (in his qaul qadim), ${ }^{21}$ scholars of Maliki, ${ }^{22}$ Hambali $^{23}$ and Zaidiyyah. ${ }^{24}$

Their reason is that, an apostate person is facing two situations, i.e. either to remain as an apostate person or to repent and revert to Islam. These two situations give effect to the right of possession of his property if he continued to be an apostate person and sentenced to death, therefore, his apostasy is considered as the cause of dissipation of the honor of his property. Therefore, any transaction made by him including hibah is void automatically. If he chooses to revert to Islam, his reversion is considered as the cause of the existence of honor of his property and any transaction made by him as related to his property such as hibah is considered as valid. ${ }^{25}$

The writer agreed with the second view uttered by Imam al-Shāfi' ${ }^{\prime}$ (in his qaul jadid) ${ }^{26}$ because it seems to be a strong view. This is based on the authorities provided by them as stated above. Another reason which can be added here is that an apostate person normally will be stressful either from the court (which will impose punishment upon him if he still holding apostasy) or from the community (who will look down on him abhorrently). Generally, dealing with the property of a person who is facing a great pressure (such as apostate person) is not stable and not given any benefit to

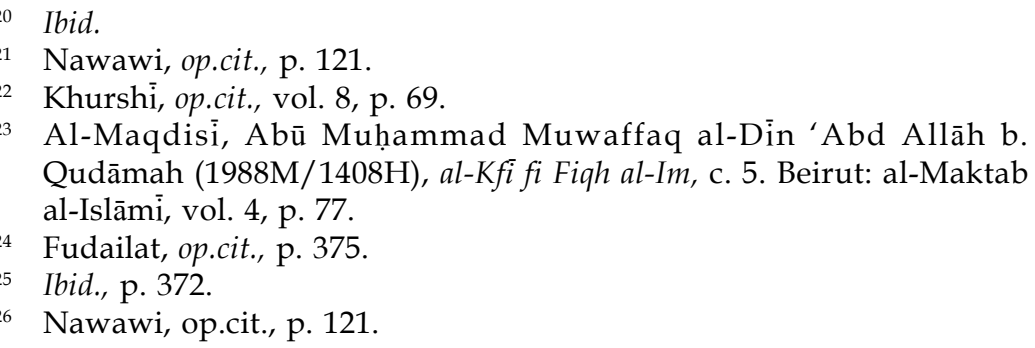


Jurnal Fiqh: No. 3 (2006)

him. Therefore, the step to cancel all dealings of his property is the best way to save the property from being destroyed. This is important in order to protect the right of his family to that property if he were to revert to Islam. What is meant by the right of his family here is the right of maintenance, right of inheritance, etc. These rights will be returned to them if the apostate person repented.

\section{Change of mazhab and its effect towards hibah}

There are differences in opinion among Muslim jurists from different sects regarding the issue of hibah.

\section{Differences of opinion among jurists in main elements}

Among the basic elements which are disputed by jurists in the issues are:

\section{Conditions of ijab and qabul in hibah transaction}

Muslim scholars unanimously agreed that 'aqd is the basic principle to determine the validity of hibah. Nevertheless, they are in different opinion as regards to what is needed in the 'aqd of hibah. The majority of the Malikis, Shafi'is, Hanbalis, Imam Zufar and others viewed that ijab and qabul (offer and acceptance) shall be executed in order to validate the hibah. ${ }^{27}$ This is due to the reason that hibah is similar to other transactions. On the other hand, Abu Hanifah, Abu Yusuf, Muhammad and others viewed that ijab is sufficient to validate a hibah. Their authority is that hibah is a voluntary gift from wahib (donor). If the validity of hibah depends on the qabul (acceptance) of the donee, therefore, it is not a voluntary gift (tabarru') in nature..$^{28}$

27 Ibn Rusyd, Muhammad b. Aḥmad b. Muhammad al-Qurțubì (n.d.), Bidāyat al-Mujtahid wa Nihāyah al-Ikhtiyār lī Ta'līl al-Mukhtār, Beirut: Dār al-Ma'rifah, vol. 3, p. 48; Jamaludin Aqil (1978), 'Aqd al-Hibah, Kaherah: Dār al-Hudā, pp. 44-45.

28 Jamaludin, op.cit., pp. 44-45; Badran Abu Ainain (n.d.), al-Mawarith wa al-Wasiyyat wa al-Hibah fi al-Shari'at al-Islamiyyah wa al-Qanun, Iskandariyyah: Muasassah al-Syabab, p. 218. 
The writer observed that what is important is the offer from the donor because the property which has been put as a hibah is his property. Therefore, the offer from his part is the most crucial. Regarding the acceptance of the donee, it can be substituted with an act which shows that he accepts such hibah.

In the case of Awang bin Abdul Rahman v. Shamsuddin bin Awang, ${ }^{29}$ the question of hibah arose without sufficient proof. The Syariah Court had set aside the claim for declaration of hibah between the deceased (Nik binti Abdul Rahman) before her death and the plaintiff. This is because it was done in an inappropriate manner i.e. offer and acceptance. ${ }^{30}$ According to the judge, offer and acceptance are important in determining the validity of hibah. Nevertheless, if it was done in majlis hibah, the acceptance from donee is unnecessary. His view was based on Article 841 of the alAhkam al-'Adliyyah. This view seemed to be parallel with the view pointed out by Hanafi scholars.

\section{Law on hibah in several Islamic countries concerning 'aqd}

Section $558^{31}$ of al-Qanun al-Madani al-Urdunì No. 43/1976 of Jordan stipulates the condition of acceptance to validate a hibah. Qanun al-Ahwal al-Shakhsiyyah li al-Muslimin No. 43/ 1991 of Sudan also stipulates the same provision under section 268 "Hibah is valid with the existence of offer and acceptance. It is completed by al-qabd."

Jordanian and Sudanese authorities had taken into consideration the view of majority scholars on this issue.

\footnotetext{
[1997] 2 JH 193.

Syarbini, op.cit., vol. 2, p. 379.

31 This section reads: "Hibah is created by offer and acceptance. Such hibah is complete by al-Qabd (receipt)."
} 
Jurnal Fiqh: No. 3 (2006)

However, the same section also stated that al-qabd or receipt of the property which has been put under hibah is considered as acceptance.

Qanun al-'Uqud al-Maliyah of Egypt basically requires a contract between the giver and the receiver. ${ }^{32}$ Requirements of 'aqd of hibah are as follows:

a. Such 'aqd is made solemnly, not a joke.

b. Such 'aqd is clearly shows the intention of parties involved or in other words, it is free from any defect which eliminates consent.

c. The chain of offer and acceptance by the giver and the receiver. ${ }^{33}$

Acceptance from the receiver is the most essential element in contract of hibah of the law of Egypt as provided under Qanun No. 131/1948. ${ }^{34}$ It must be done by any means. The reason is that, hibah is a contract which must be done by will and consent of the parties involved (giver and receiver). A receiver can accept his hibah either by himself or his representative. A minor who attains the age of mumayyiz can accept hibah made to him. This is because hibah is a gift which its benefit returns to him. Law of Egypt also allows beneficiaries to accept hibah which has been given to their deceased family members before they (the deceased family members) before they accept such hibah. ${ }^{35}$

The law of Egypt also stipulated that hibah related to immovable property such as land, shall be made in writing or registered. For movable property, such condition is not necessary. ${ }^{36}$ Jordanian law differentiates between direct and 
indirect hibah. What is meant by direct hibah is hibah made by a person to another person without business intervention, whereas, indirect hibah is like a hibah of the profit of a person to his partner in a business. The first type shall be made in writing but not necessarily for the second one. ${ }^{37}$

\section{Does al-Mu'atah Can Replace Ijab and Qabul?}

Muslim scholars had discussed about hibah by way of al$M u^{\prime}$ atah or an act without showing the pronunciation of hibah. There are two views regarding this matter.

The first view: Such hibah is invalid because hibah is a transfer of ownership. Therefore, offer and acceptance are needed so that such ownership does not raise any other meaning. This view is accepted by majority of scholars such as al-Qadi, Abu al-Khattab, Ibn Hazm, majority of Shafi'i's and others. ${ }^{38}$ They also argued that hibah should be made in consent. Since consent is a hidden matter, it needs to a pronunciation which shows the intention to create hibah. ${ }^{39}$

The second view: Hibah by way of al-Mu'atah is valid if it really shows the meaning of giving or hibah. This view is uttered by Hanafi, Maliki, Hambali and some scholars from Shafi' ${ }^{\prime} .^{40}$ One the authority given is that hibah is similar with other mu'amalah transactions, which does not need any pronunciation to be regarded as valid. This is because that there is no clear injunction which stated that pronunciation

37 Hasan al-Fakhani (1979), al-Wasit fi Sharh al-Qanun al-Madanì alUrdunī, No. 43/1976, al-Dar al-'Arabiyyah li al-Mausu'at, vol. 2, p. 878.

38 Jamaludin, op.cit, pp. 47-48.

39 Ibid., p. 48

40 Syarbini, op.cit., vol. 3, pp. 2-4; al-Kasāni, al-Dīn Abū Bakr b. Mas'ūd (1986M/1406), Kitab Bad'i wa al-Șan'i fi Tartīb al-Syar'i, c. 2. Beirut: Dār al-Kutub al-'Ilmiyyah, vol. 5, p. 134; Ibn Qudamah, op.cit., vol. 6, p. 283. 
Jurnal Fiqh: No. 3 (2006)

of contract is obligatory. What is important is the existence of consent between parties involved. ${ }^{41}$

The third view: If the subject matter of hibah is only miniature things such as pencil, notebooks etc., therefore it can be made through al-Mu'atah. However, if the subject matter of hibah is of a valuable things and large, it must be done through the pronunciation of 'aqd. This is the view of al-Karkhi (one of the scholars of Hanafi)..$^{42}$

The view which stipulates the pronunciation of 'aqd in hibah is the preferred view, based on two points:

i. Anything which related to property shall be controlled and maintained meticulously in order to avoid disputes between the parties involved. Hibah is a transfer of ownership from one to another and it is exposed to certain disputes at the end of the day, especially between the receiver and the descendents of the giver after his death. Therefore, 'aqd is the best way and shall be made in front of 'adil witnesses and also shall be recorded.

ii. 'Aqd will differentiate between hibah and other matters such as lending (whether it is 'ariyat, ibahat or qard). If a hibah is uncertain (no pronunciation of 'aqd), in the future the giver might claim that such gift is made in form of lending. This will bring a new problem to the party concerned.

In the case of Eshah binti Abdul Rahman v. Azuhar bin Ismail, $^{43}$ the Honorable Judge Haji Ismail Yahya had decided

41 Muhammad al-Hattab (1992), Mawahib al-Jalil, Beirut: Dar al-Fikr, vol. 4, p. 228; al-Dusūqi, Syams al-Dīn Muhammad 'Irfah (n.d.), Hāsyiyah al-Dusūqi 'ala al-Syarh al-Kabir, 4 j. Beirut: Dār al-Kutub al-'Arabiyah, vol. 3, p. 3; Ibn Rusyd, op.cit., vol. 2, p. 161; Ibn Qudamah, op.cit., vol. 6, p. 283; Jamaludin, op.cit., p. 48.

42 Jamaludin, op.cit., p. 48.

43 [1997] 2 JH 219. 
that hibah concerning land GM 1972, Lot 2371 Mukim Kuala Paka, Dungun is valid although it happened by way of transfer of ownership and registration, not by way of offer and acceptance as insisted by Shafi' $\bar{i}$ scholars. The decision of the judge is equivalent to the view pointed out by Maliki, Hanafi, Hambali and some scholars of Shafi' $\bar{i}$ as mentioned ante.

\section{Law of Hibah in Several Islamic Countries Regarding al- Mu'atah}

Qanun al-Ahwal al-Shakhsiyyah li al-Muslimin No. 43/1991 of Sudan provides a provision as regards to this matter i.e. under section 269 "(1) Offer of hibah is valid by any means which shows a free transfer of ownership either by way of pronunciation or writing or sign which can be understood. (2) Hibah by way of al-Ta'ati (an act of giving the hibah property) is valid." 44

Qanun al-'Uqud al-Maliyyah of Egypt also provides the same provision. This provision divided contract into two categories:

a. Al-Ta'bir al-Sarih, i.e. the occurrence of 'aqd by way of pronunciation, in writing or understandable sign. The pronunciation used shall be referred to the meaning of hibah. This includes any act or sign which shows the hibah of the giver to the receiver such as the giver hand over his hibah property to the receiver.

b. Al-Ta'bir al-Dhimni, i.e. the parties involved (giver and receiver) conduct a process which shows the hibah, such as conducting the transfer of ownership etc. This conduct can be regarded as indirect conduct. $^{45}$

$44 \quad$ Section 269 (1) and (2).

45 Jamaludin, op.cit., pp. 62-63. 
Jurnal Fiqh: No. 3 (2006)

\section{Does the Reception of Property (al-Qabd) a Condition for a Valid Hibah?}

The scholars had discussed about this matter. Some scholars of Hanafi ${ }^{46}$ put a condition of al-qabd as the basic principle of hibah. It means that without al-qabd, a hibah made is not valid. According to Malik ${ }^{47}$ and Zahiri ${ }^{\overline{4} 8}$ sects, al-qabd is not a condition for the validity of hibah, without it the hibah is still valid. ${ }^{49}$ According to the majority scholars, al-qabd (reception) of property of hibah is the fundamental condition for the validity of hibah besides the consent of wahib (the giver). Among them who agreed with this view is Abu Bakr, 'Umar, 'Uthman, 'Ali, al-Nakha' $\bar{i}$, al-Thawri, al-Hasan bin Salih, al-Anbari, al-Shafi' ${ }^{\prime}$ etc. ${ }^{50}$

Their authorities are:

i. The saying of the Prophet p.b.u.h "And there is no property for you except for what you have consumed and what you have worn until it is broken or anything you have given as a gift until you persists on it." 51

In this Hadith, the Prophet p.b.u.h had mentioned that a gift which has been made by a person is not considered as a gift until he persists on it. The word 'persist' connotes the delivery of goods of hibah to the person whom hibah is made. ${ }^{52}$

ii. Analogical deduction to other types of transactions such as 'ariyah and qard (loan). These types of

46 Aini, op.cit., vol. 9, p. 198.

47 Zuhaili, op.cit., vol. 5, p. 19.

48 Dusuqi, op.cit., vol. 4, p. 101; Ibn Rusyd, op.cit., vol. 2, p. 324.

49 Abū Muḥammad 'Alì b. Ahmmad b. Sa'ì b. Ḥazm (n.d.), Qāherah: Dār al-Turāth, vol. 9, p. 121.

50 Daradakah, op.cit., vol. 2, p. 210.

Ibid.

52 Abu 'Abd Allāh al-Hakim al-Naisuburi (n.d.), Al-Mustadrak 'ala alSahihayn, Beirut: Dār al-Kitab al-Arabi, vol. 2, p. 534. 
transactions will not be formed unless it is delivered to the borrower. ${ }^{53}$

Their arguments is the athar of the Companions of the Prophets p.b.u.h, among others the saying of 'Abdullah bin Mas'ud which means "A gift or charity are permissible whether the qabd (reception) is existed or not." 54

The writer viewed that qabd is not a fundamental condition for hibah, but it can be a indication for a person who received the hibah. It means that qabd can replace the position of qabul (acceptance) in hibah transaction. ${ }^{55}$

\section{Law of Hibah in Several Islamic Countries concerning al- Qabd}

Qanun al-Ahwal l-Shakhsiyyah li al-Muslimin No: 43/1991 of Sudan provides for this matter under section 270:

(1) Qabd (reception of hibah property) can take the place of qabul (acceptance) by pronunciation, (2) Qabd divided into two: haqiqiy and hukmiy. The interpretation as follows: (a) Qabd haqiqi (for immovable property) as living in a given place or to rent it or to possess it or executing transactions which show the right of ownership. (b) Qabd haqiqi for movable property is to acquire it. (c) Qabd hukmi for immovable property is the giver will vacate it until the transfer of ownership to the receiver complete without any interruption. It also happened by way of registration of such property (as the receiver's property) or deliver of the key.

53 Daradakah, op.cit., vol. 2, p. 210.

54 Ibid.

55 Abū Muhammad al-Zaila'i (n.d.), Nasb al-Rayat, al-Maktabah al-Riyad al-Hadithah, vol. 2, p. 124. 
Jurnal Fiqh: No. 3 (2006)

\section{Hibah Made by a Disease Person at the time of Marad al-} Maut (Death-Sickness)

Disease which attains the level of marad al-maut (deathsickness) is a critical disease which would render the sufferer to death. There are several characteristics of this kind of disease:

i. Such disease will render the sufferer to death.

ii. Death resulting from such disease happened within the period of one year or after that.

iii. Disease which would render the sufferer to be unconscious about anything that relates to material. ${ }^{56}$

According to Islamic law, if a person died at the time of marad al-maut, hibah made by him should be categorized as will, ${ }^{57}$ inter alia, such gift shall be more than one-third. If a person who suffers from such disease and creates hibah at that time, such hibah will be subjected to inter vivos, i.e. transfer of ownership of the giver to the receiver. ${ }^{58}$

\section{Law of Hibah in Several Islamic Countries Pertaining to Marad al-Maut}

There are provisions as relate to this matter. Al-Qanun alMadani al-Urduni No: 43/1976 provides under section 206:

"Effect of any contract will be imposed to the parties involved and their successors without defaulting any rules pertaining to inheritance, as long as it is uncertain from the contract made or demeanor of action or any legal maxims which show the contrary that such effect cannot be imposed..."

56 Badran, op.cit., p. 223.

57 Ridwan Awang (1994), Undang-undang Tanah Islam, Kuala Lumpur: DBP, p. 370; Article 1595, The Mejelle.

58 Sayyid Sabiq (1983M/1403H), Figh al-Sunnah, Beirut: Dār al-Kitab al'Arabi, vol. 3, p. 391. 
This section clearly mentioned that any contract cannot be imposed or has no effect if there is a default in such contract. Among the defaults is 'demeanor of action' of any contract. The relation between that phrase and the issue of marad al-maut is that any act of a person suffering from such disease which relates to administration of his estate is regarded as abnormal and irregular. This situation will give effect to the contract made (which is related to the property). Therefore, in order to secure the right over his property and his successors (after his death), contract of hibah made in marad al-maut situation shall be limited to certain amount, as similar as will. ${ }^{59}$ The same provision applies in Egypt. ${ }^{60}$

\section{Withdrawal of Hibah's Property}

According to Hanafi jurists, 'aqd hibah is not lazim (no absolute implication), so that the giver has right to withdraw his property which is given to the receiver. This is based on the hadith of the Prophet (p.b.u.h) to the effect:

"A giver has right over the property given as long as it is not substituted."61

This hadith clearly shows that hibah which is not substituted by anything can be withdrawn by the former owner. Nevertheless, to withdraw such hibah is regarded as dislikable because it shows the deficiency of the giver's dignity. ${ }^{62}$

According to majority jurists i.e. scholars of Malik $\bar{i},{ }^{63}$ Shafi' ${ }^{6}{ }^{64}$ and Hambali, ${ }^{65}$ 'aqd hibah is lazim (has absolute implication). Therefore, it cannot be revoked or withdrawn

59 This can be construed from sections 544 and 545 of al-Qanun al-Madan $\bar{i}$ al-Urduni.

60 Section 492, Qanun No. 131/19478 of Egypt.

61 Zaila'i, op.cit., vol. 4, p. 125.

62 Kasani, op.cit., vol. 6, p. 127.

63 Dusuqi, op.cit., vol. 4, p. 110.

64 Syarbini, op.cit., vol. 2, p. 401.

65 Ibn Qudamah, op.cit., vol. 6, p. 278. 
Jurnal Fiqh: No. 3 (2006)

by the former owner. They based their view to a few hadith, among others:

i. The saying of the Prophet (p.b.u.h) to the effect " $A$ person who'd taken back his gift is like a man swallowed back his own vomit." 66

ii. The saying of the Prophet (p.b.u.h) to the effect " $A$ person who'd taken back his gift is like a dog swallowed back its own vomit." 67

They exempted a situation where a hibah made by a father to his son; in this case, it is permissible for the father to take it back. This is based on the hadith "It is not permissible for a person to withdraw what he has given to another person except for a father to take back what he has given to his son." 68

The opinion of majority jurists is considered favorable, because those hadith mentioned clearly insulting one who withdrawn his hibah. It shows that it is not permissible (haram) for a person to withdraw back his gift. This matter will lead to a chaos in society and certainly it is not allowed in Islam.

In Eshah binti Abdul Rahman v. Azuhar bin Ismail, ${ }^{69}$ the plaintiff (defendant's adopted mother) applied for withdrawal of hibah i.e. the transfer of title of the land GM 1972, Lot 2371, Mukim Kuala Paka, Dungun, Terengganu from the defendant. The Syariah High Court of Terengganu held that the withdrawal of hibah made is against Islamic law. Therefore, the application was rejected. The Honorable Judge Haji Ismail Yahya rejected the claim and stressed that there are several hadith which prohibit a person from taken back his hibah except for a father to take back what he has

66 Muhammad b. Isma'îl (1960M/1379H), Subul al-Salām, 4 j. c. 4, Pulau Pinang: Maktabah Dār al-Ma'ārif, vol. 3, p. 90.

67 Ibid.

68 Zaila'í, op.cit., vol. 4, p. 124.

69 [1997] 2 JH 219. 
given to his son. In this case, the defendant is not her son, but merely adopted son. Therefore, she cannot withdraw her hibah made in favor of the defendant. The decision above is in line with the opinion uttered by the majority jurist above.

\section{Law of Hibah in Several Islamic Countries Relating to the Withdrawal of Hibah}

Qanun al-Ahwal al-Shakhsiyyah li al-Muslimin of Sudan has taken a middle way between the two opinions mentioned, as under section 280 provides:

It is permissible for a giver to withdraw his hibah's property: (a) if reception of that thing (Qabd) is not occurred from part of the receiver. The reception is permissible without the existence of the receiver. (b) If reception occurred, the giver cannot withdraw it except by the receiver's consent. If the receiver does not consent, the giver may apply for dissolution of contract of hibah at the court by giving reasonable grounds.

Egyptian law adopted the majority's view. Under section 500 of Act 131/1948, it mentioned:

(1) It is permissible for a giver to withdraw his hibah if he obtained consent from the receiver. (2) If the receiver does not consented to it, the giver may apply for withdrawal through the court. This application is permissible if it is based on the acceptable infirmity and no hindrance exists.

This provision is clearly followed the majority view which stated that hibah is considered as contract lazim. If the giver wanted to take back his hibah property, he shall obtain consent from the receiver. If the receiver refused, he has no right over the property anymore. The withdrawal without consent of the receiver can be regarded as illegal dispossession that would amount to crime. This provision also gives a right for a giver to withdraw his hibah through 
Jurnal Fiqh: No. 3 (2006)

the court such as breach of betrothal agreement. ${ }^{70}$ The writer viewed that hibah in betrothal cannot be included under the type of ordinary hibah, because the hibah is made in a cause of marriage, not in ordinary cause, which came from the feeling of relationship between the giver and the receiver. When the breach of betrothal occurred, if it will affecting the dignity of family, the party involved has strong ground to take it back (through the court) the hibah given at the time of betrothal, because the cause of giving is not in existence anymore, therefore it is just for the involved party to apply to the court to withdraw the property given during betrothal, moreover if it affects the dignity of family.

Another reasons or grounds of withdrawal are poorness, necessity etc. This matter is provided under section 501:

(b) a giver is incapable to provide for himself necessary things which in line with current situation of the community or incapable to pay the debt as mentioned in law...(c) a giver is blessed with a children after hibah has been made and his children is alive until the withdrawal time, or he has been blessed with a children who, in his presumption, is dead at the time of he creates such hibah, but it is proven otherwise.

A question arose here is whether the court has jurisdiction to issue an order for the receiver to return back the hibah's property to the giver, or whether the court has to obtain consent of the receiver before issuing such order. If the court follows the first, it is in line with Hanafi's view that allowed the withdrawal without consent of the receiver. The Egyptian legislators seemed to construe the sections mentioned above with the second, i.e. the court shall

70 Miwad, op.cit., No. 131/1948, vol. 1, p. 966. 
obtained consent from the receiver. ${ }^{71}$ This is based on section 504 (1) which provides for remedies in favor of the receiver if the giver obtain back the property without his consent. The section reads:

(1) When a giver possesses the hibah's property without consent of the receiver, or without legal proceeding, he is liable to any damage caused over the property either it is caused by him or other factors...

The writer views that this section does not actually interrupting the jurisdiction of court to issue orders including an order that the hibah's property shall be returned back to the former owner of such property although without the receiver's consent. This section separated between two matters:

i. Possession of the giver over the property without the receiver's consent.

ii. Possession of the giver over the property without legal authorization.

This separation of these matters shows that the court has power to issue any order which it thinks fit without waiting for the consent of the receiver.

As a conclusion, Egyptian law of hibah, in question of withdrawal of hibah's property, follows the majority's view. Nevertheless, in certain situations, the court may use its power to issue any order without obtaining receiver's consent which is parallel with Hanafi's view.

Meanwhile, Jordanian law of hibah seems to follow majority's view. According to Jordanian legislators, any contract which relates to property is divided into to categories:

i. A contract which become lazim (bind) for both parties

$71 \quad$ Ibid., p. 970. 
Jurnal Fiqh: No. 3 (2006)

ii. A contract which is lazim (bind) for one party only. ${ }^{72}$

The first example is buying and selling contract. If it is done, such contract would bind both parties (buyer and seller). The phrase "bind" here means both parties has no right over the property to return back or to obtain it back except by consensus ad idem to do that. ${ }^{73}$

The second example is contract of wadi'ah where a person is entrusted to guard certain property; he is bound to that agreement.

Looking at both categories, contract of hibah may be inserted under the second category i.e. the giver, when he offers for hibah purpose, is bound by his offer and he has no right to withdraw it back. This is parallel with views uttered by the majority jurists.

Other evidence that shows that hibah is lazim (bind) is section 87 , which shows that every contract has its legal effect, including hibah. This section is actually construes the meaning of contract itself. The section reads "Contract ('aqd) is an offer made by the offeror and acceptance made by the offeree in which they are bound to each other and it will give effect to the contract entered, followed by the commitment of both parties in which the obliged to do to each other."

Thirdly, section 244 provides "Any 'iqalah (revocation of contract) is complete by offer and acceptance in one occasion and also complete by way of action that shows the intention to revoke...".

72 Fakhani, op.cit., vol. 2, p. 795.

73 Ibid. 